\title{
Arab Culture and Urban Form
}

\section{Anthony KiET}

Looking at the evolution of the Arab city from an urban design perspective, Anthony Kiet discusses the cultural impacts of westernization and how they are affecting urban form. He shows us how the Western planning model seems to be contributing to the creation of a modern antithesis of the traditional Arab city.

Current changes in the economic and social conditions throughout the Middle East are more radical now than ever. The region is undergoing transition from traditional economies and societies to one of modern development which has yet to find any real stability. This is most clear and most evident in the field of urban design and planning, for it is the largest and most visible of a community's built forms. Many who have visited or are currently residing in the Middle East can point to the many changes brought about through growth and transition, whether it is in the form of the built environment, the dominance of the automobile in the cities' transportation networks, or the increase in squatter communities and people at the edges of the town.

Much contemporary planning work taking place in the Middle East in recent years has been in the form of new town planning or master planned communities. However, many issues that arise from the growth of these Arab communities can be attributed to planners and designers tasked with the design of these cities without proper knowledge of the region, its constraints, and its culture. The lack of trained town planners and architects can be legitimately considered a contributing cause of the basic mistakes committed in the planning and expansion of most Arab metropolises (Berger, 1974; Shiber, 1974). Local engineers and architects, while knowing the local habits and conditions better than the foreign expert, are not adequately trained to translate their valuable knowledge into urban design and planning. The foreign consultant, though perhaps well trained, is not well versed in local characteristics to effectively produce sound policies and planning solutions.

In this article, I will discuss and analyze the traditional urban form of the Arab city, the impact of culture, and how it has affected the form of the city. I will also discuss the impacts of the Western planning model, which has contributed to creating the modern antithesis of the urban Arab city.

\section{Traditional Urban Form}

While historic Arab cities show a variety of origins and growth patterns, they were nonetheless established by a common set of social, geographic, and religious factors leading to similar morphological principles developing the urban fabric (Ben-Hamouche, 2009; Bianca, 2000; Lapidus, 1969; Saqqaf, 1987). In the urban design context, morphology refers to the underlying factors of urban form that draw upon society's attitudes towards and in relation to physical elements and spaces (Franck, 1994). Formally speaking, the Arab City can be seen as an integration of multiple cultures and eras as they came into contact with the Islamic culture, eventually leading to the urban structures and morphological form common in Arab cities today.

Like most cities, the original locations of Arab settlements depended on availability of natural resources such as water supply, locations of existing trade routes, and sometimes on the religious significance of certain places. Many times, it was a combination of these factors and others that contributed to the settlement's site and growth. The holy city of Mecca, for example, was already a trade route before becoming an important pilgrimage site. Medina developed in an oasis for its water supply and continued its growth due to the frankincense trade route. Other cities such as Damascus, Cairo, and Baghdad developed upon strategic geographic location benefitting from water sources and along trade routes as well.

Note: This paper is based in the author's master's thesis under development at CRP's MCRP program.
Anthony Kiet holds an architecture degree from Cal Poly and is currently developing his master's thesis in CRP. He works as an urban designer at EDAWIAECON San Francisco. 
While the origin of the city was dependent on mainly external factors, the Arab city's traditional development pattern was affected by a variety of other factors, one of which is the division of the social hierarchy (Bianca, 2000; Lapidus, 1969). Traditionally, the camps, residences, palaces, and citadels of the ruling class were set apart from the commoners. This would mean that while the larger, more ornate structures were used as landmark structures isolated on the edges of major cities away from the urban center, the buildings associated with the working classes, the local crafts and trade, the mosques and smaller religious institutions, the community facilities, and the common residences were weaved together in the urban fabric.

Another important factor contributing to the growth patterns of Muslim cities are ethnic migrations (Saqqaf, 1987). As these migrations occurred, it led to the development of separate town units, or suburbs, slowly connecting themselves to the urban center starting at the main gates and growing along the major traffic routes outside the city. Cities such as Aleppo or Damascus demonstrate this informal growth pattern with their suburbs extending well past the walled city limits. Accordingly, as cities began to grow, community centers began to shift while older areas of the city became abandoned and newer communities developed.

According to Lapidus, traditional Arab settlements developed in two distinct ways: either "planned" or "spontaneous" urban patterns. The former growth pattern is generally defined by the formal layout of palace cities in response to military concepts and representations of power and royalty. These development patterns are not as common in the typical Muslim city as the latter growth pattern. Because most Muslim cities were guided by the culture and social order of Islam, they developed in a more organic or spontaneous manner characterized by private communities and social groups. Rather than being designed by a formal plan, the Arab city vernacular grew according to the needs of the populace (Ben-Hamouche, 2009).

Starting at the center of the city, the main land-use pattern as described by Bianca focuses on the "multifunctional core structure enveloping or at least partially surrounding the central mosque by different layers of interconnected souks (the typical form of Arab shops and markets)" (Bianca, 2000: 143). Interconnected within are commercial facilities in the form of caravanserai, other civic and educational buildings, and other religious

Figures 1 \& 2 Traditional Arab urban form in the cities of Mardin and Aleppo, Syria. (source: www.wayfaring. info/index.php?s=syria)

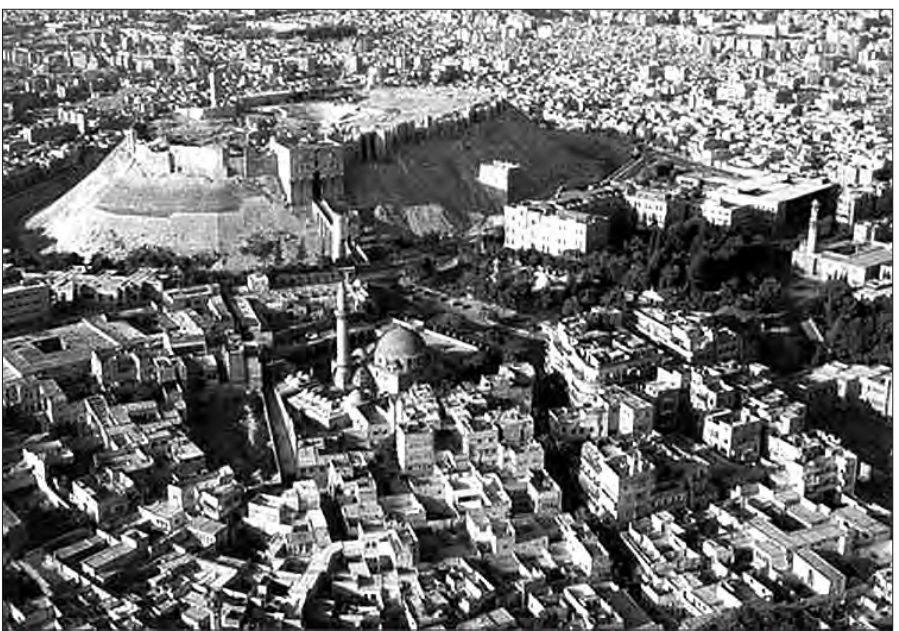
and social structures. Together, the congregation of facilities and structures create a massive mosque complex with only the minaret and large dome of the mosque creating a break in the roofscape. The central courtyard of the complex becomes the primary public open space of the complex and sometimes for the city as a whole. As the grand mosque becomes the center structure of the city surrounded by the markets, the circulation system

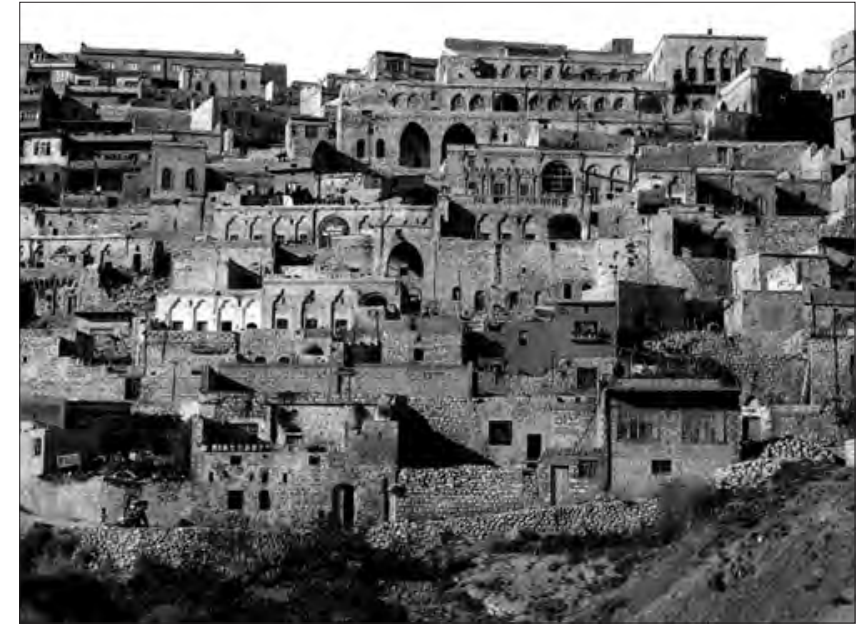


of the souks becomes the primary access of the central complex, often with multiple entry gates on each side. Multiple other smaller open spaces located off the main pathways created by the caravanserai and smaller religious facilities become specialized public areas with distinct social functions balancing the community needs (Shiber, 1974).

Visually, the central mosque and accompanying facilities appear as a singular structure, and yet experientially, the center of the complex is divided by social behavior and architectural cues. Architectural details such as gateways, passages, thresholds, and detailed doorways indicate a change in function, and subtle cues in spatial patterns indicate a change in accepted social behaviors. Throughout this center, the visitor experiences a set of interconnected and separate spaces yet a homogenous urban whole.

Connecting the central facility to the remainder of the town are a number of main roads acting as spines running down to the outer walls and to the exterior of the city. Each of the spines are lined with shops that frame the pedestrian pathways and take advantage of all potential clients as they walk through the community. A secondary function of these spines, besides connecting the central mosque to the outer rings of the city, is to serve as "protective shields" (Bianca, 2000: 148) hiding the residential districts from intrusion. At the crossroads of the main spines are intersecting narrow alleyways, marked by small gates, indicating the entrances of residential districts. These passages indicate the filtering of the flow of people as the public sphere turns to the private sphere managing the sacred spaces of domestic Arab life in the city.

The residential quarters made up most of the remainder of the city, growing from the space left between the main pedestrian spines and the city center. Social class dictated the growth patterns starting at the center. The most prestigious and wealthy families lived in the compounds closest to the central mosque while those of the working class settled closer to the periphery. Nearest the outer wall, the remaining open space was used as agricultural land providing food and sustenance to the city. In addition, some of the land was used for cemeteries, local crafts, or residential expansions. Subject to the Islamic culture, however, was the rule that unowned land had the status of dead land. This principle allowed residents to develop and own the land as they saw fit. As a result, as housing units expanded, open space was taken over by surrounding domiciles reducing the agricultural land supply but increasing the residential stock. Likewise, as the city grew and expanded, the outer walls were shifted outward at each stage of growth to provide more space for more people.

Residential units themselves developed according to a set of principles dictating the form and morphology of the surrounding neighborhood. As described by Ben-Hamouche (2009), one such principle, the right of precedence, is considered priority when developing between neighbors and other families. Due to the importance of privacy, when one home locates openings facing a certain alleyway or pathway, the opposite property cannot locate an opening facing the same side.Consequently, the building process required complex site designs resulting in the organic organization of interlocking residential units developing the complex form of the urban fabric. In addition, any overhead space along paths and

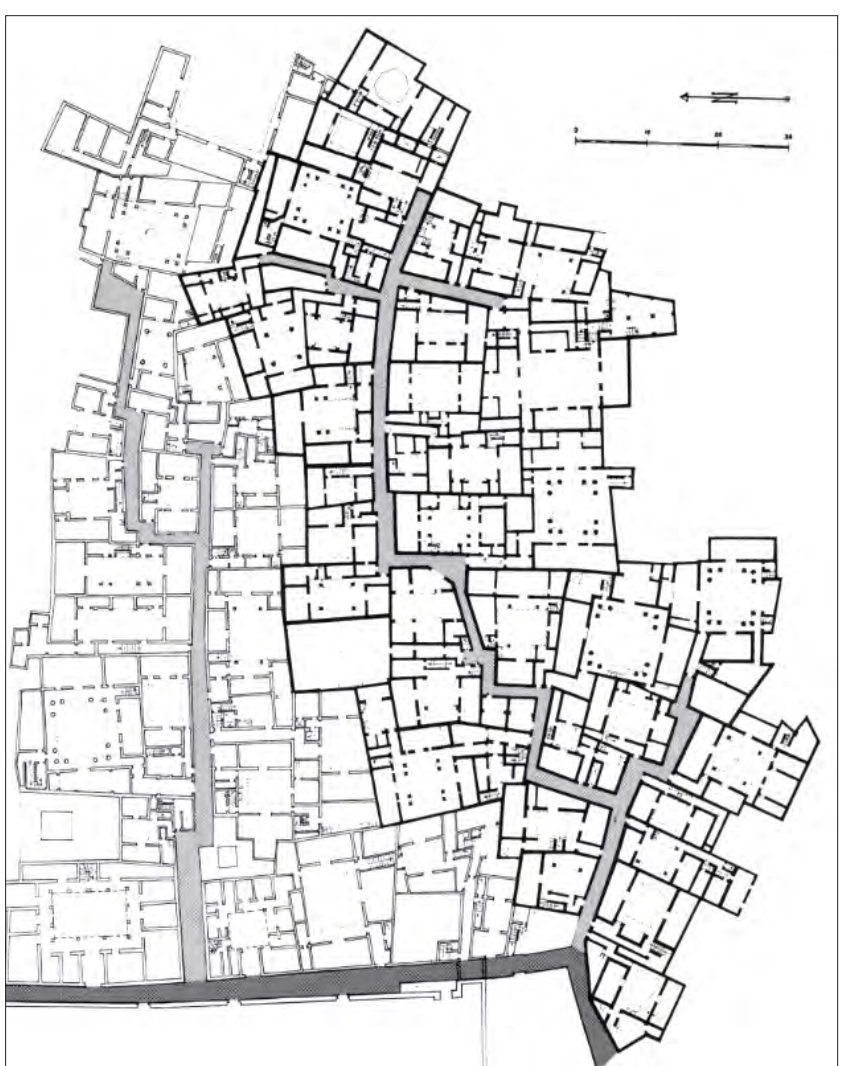

Figure 3

A traditional residential cluster in Fez containing a variety of self contained courtyard houses and alleyway circulation. (source: Bianca, 2000) 
streets were subject to appropriations by residents for the expansion of their homes. The following of this idea led to encroachments on streets, cantilevered segments of structures, projections into the public sphere such as other rooms and lattice structures on windows and openings for privacy called mushrabiyas.

The residential unit is also subject to a system of subdivision, further increasing the complexity of the urban form. This arises mainly due to the Islamic law of inheritance and the conditions associated with the division and sharing of a preexisting unit (Ibnu al-Rami, 1995). As the residential unit fragmented into smaller parts, new components were often added such as corridors, staircases, doors, and windows. Although common public facilities would remain intact, open spaces such as larger courtyards were divided into smaller ones, and buildings would be set back to accommodate easements to allow for new passageways creating constant changes in the morphology of the residential areas.

Although subdivisions occurred regularly, additions were much more common, allowing for expansion of the existing city framework. As mentioned prior, residential units often formed their own neighborhoods as they grew in size and created their own social unit (Lapidus, 1969). As such, each neighborhood controlled their own public facilities, such as a local mosque, one or more schools, and public courtyards and fountains. In most cases, each neighborhood was defined at the perimeter by the set of contiguous outer walls of the group of houses laid out around a shared dead-end alleyway. At the alleyway's opening would be a small gate controlled by the owners to control the flow of people into the private space. Viewed together with other small neighborhoods and residential clusters, it formed a larger neighborhood unit complete with their own open spaces, shared facilities, and interior circulation system connected to the urban fabric by the larger pedestrian pathways and spines.

The morphology of the Arab City is created by a repetition of cellular residential blocks and clusters at multiple scales. As each cell interconnects and is overlaid onto another residential cluster, the urban fabric becomes a system of hierarchical elements of various sized cells creating a complex pattern of unity and homogeneity. This becomes increasingly apparent as the units and subunits of the city are seen in a comprehensive fashion relative to their own architectural intent. Interestingly, as the scale increases, the division of individual units is blurred, allowing the architecture to read differently at different scales. The fact that each component of the Arab City shared the same structural principles made them completely compatible. Due to the nature of the courtyards and open spaces, connection, expansion, and integration were possible at any stage of development, allowing for maximum flexibility. While differentiation occurred in use, the form was almost completely homogenous, organized by the system of open spaces, courtyards, and circulation patterns present at every scale. In this instance, even potentially conflicting uses can be placed side by side, integrated into a single comprehensive and cohesive urban fabric.

As noted by Lapidus (1969), the morphology of the urban city becomes a breathing, organic structure fundamentally different from the sterile uniformity of replication and capable of multiplying without ever losing its essential qualities. The smallest elements are capable of representing the structure of the urban whole. Each element communicates the consistent language of form and function. Each of the city's units can stand on its own giving the user the impression of always being in the center of things, regardless of the size or scale of the structure or neighborhood.

\section{Modern Urban Form}

In the nineteenth century, industrialization had a delayed but massive impact on Muslim society (Bianca, 2000; Lapidus, 1969), much of which was transmitted through Europe's colonial expansion and development. It was 
during this time that Europe developed the tools and leverage needed to impose its supremacy and sustain its colonization into other continents beyond the adjacent and easily accessible coastlines. By 1920, large parts of the world were under European influence. However, largely due to the strength of the Ottoman Empire, most of the Islamic world, including the Middle East, was able to escape the European colonization of the nineteenth century. On the other hand, through Turkey the Ottoman Empire acted as a filter and transmitter of Western influences, which led to the beginning of the "westernization" of Ottoman architecture.

At this point in time, the western model was largely recognized as Modernism, and as such, the westernization that occurred followed the Modern Movement and its ideals. Started by Loos, Gropius, van der Rohe, Le Corbusier, and others, the Modern Movement was a reaction against social injustice and the architectural style of early nineteenth century Europe, attempting to camouflage new building typologies of the industrial age by a revival of historic styles. However, as the architectural features merely mimicked past styles and expressions, it lacked truth and relevance, and the designs were not supported by the traditions and culture. The Modern Movement's architectural forms had rejected the expression of cultural identity in exchange for functionalism and rational efficiency (Shiber, 1974).

In many areas of the Arab world, it was evident that "westernization" had taken place. Features of classical and rococo architecture were prevalent in Istanbul, and Western-type apartment houses distinctly lined the streets of new districts. As the Ottoman Empire's reign continued, important capitals such as Aleppo, Damascus, and Baghdad established new Western-style municipalities to plan urban developments (Saqqaf, 1987). Architects from France and Italy were commissioned to design important buildings and urban projects. Streets were designed in the European colonial style screening the traditional urban fabric, usually about three stories, not high enough to exceed the pre-established domestic architecture behind. In larger cities, medieval walls were torn down to make way for new residential suburban development, reminiscent of Western colonial administrations.

One of the most drastic transformations of an Islamic City happened in Cairo (Lapidus, 1969). Heavily influenced by the designs and schemes of Haussmann after a visit to Paris in 1867 for the World Fair, Muhammad Ali and his followers adopted the French plans and model. Similar to Haussmann's schemes, Ali's successors designed a new town plan on vacant land southwest of Cairo. Several new axes extended from the new city center into the old city center, cutting through the historic fabric with little regard to the physical, social, and economic impacts of the corridor development. Not only did this disturb the traditional city, but it also caused a rift in the social structure, with those more privileged choosing to live in the Westernized environment while the rest lived in the historic city. This, in essence, was the beginning of the stigmatization of the historic city as a lower social class neighborhood (Bianca, 2000).

After the fall of the Ottoman Empire, the next stage of Westernization began with

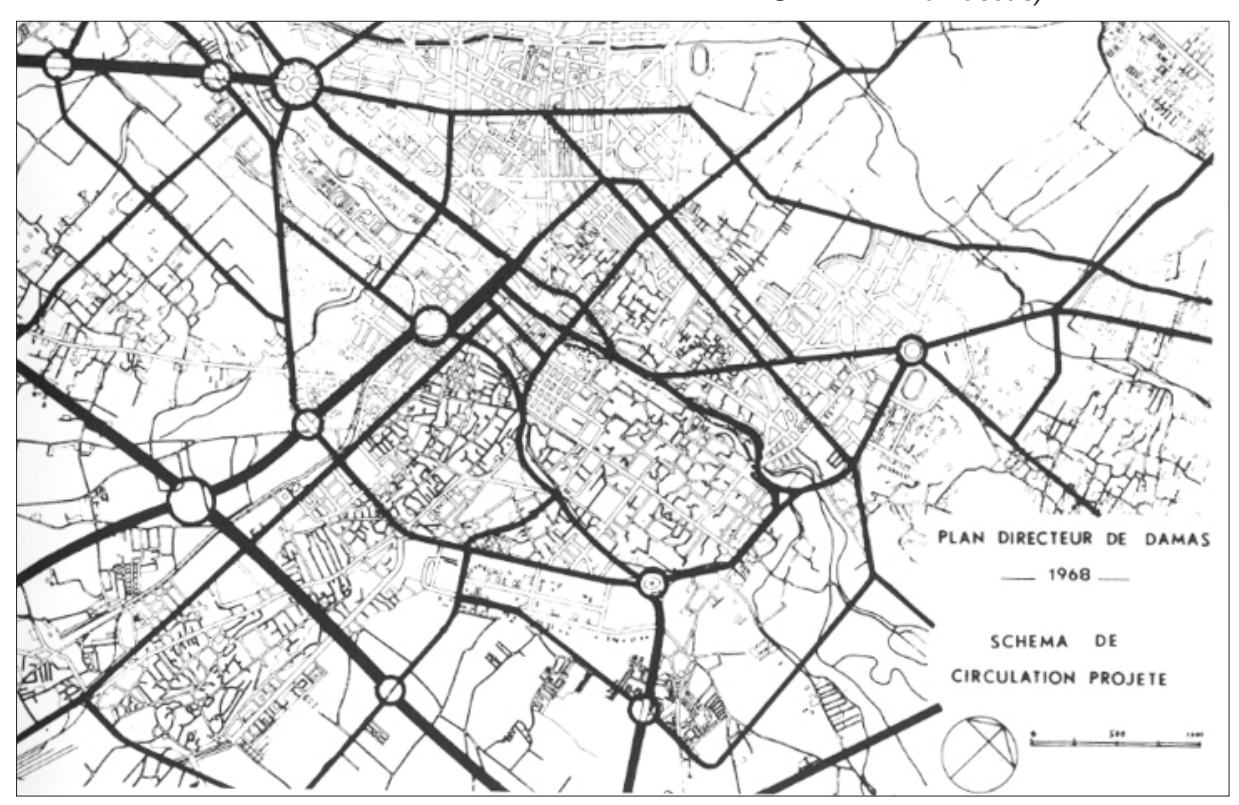

\section{Figure 4}

Master Plan of Damascus in 1968 influenced by western-style circulation planning. (source: City of

\section{Damascus)}


even greater influence. Without the strength of the former Empire, the Middle East was opened up to political influence by Western nations resulting in a number of developments within and around cities following the Western model. By the end of the second World War, the Western superpowers emerged in the dominant positions of economic, financial, and technological supremacy. Although this was the case, the period of European colonialism and imperialism within the Arab world had all but disappeared as individual countries struggled for independence. But, even with political independence, the effects of the Western model were already firmly established through their now existing governmental structures and procedures. Economic patterns set by industrialization were designed to exist and interact with Western technology. With the growth of the Western style businesses and professions in Middle Eastern cities, physical growth began to resemble the American "central business district" (Gulick, 1969). Living conditions, prestige, and education were all based upon the standards of the Western world. It is during this period that the differences between the East and the West began to fade, and the Muslim world and its traditional and cultural ideas began to integrate with the modern ones.

While ideas were integrating, the urban form remained divided based on cultural and societal differences. Cultural identity stayed in the historic city centers with the lower social classes, while the new Western practices of town planning and development became the planning style of the bourgeoisie. Issues identified by the higher social classes for abandoning the traditional city and way of life included poor accessibility, lack of services, badly maintained facilities, overdensification, poor economic conditions, and dilapidation of the housing stock (Saqqaf, 1987). The result of this mass exodus of the population is further demolition and neglect of traditional historic centers.

At this time, two types of urban planning and intervention emerged. The first was the superimposing of the new cities onto the older historic fabric by cutting out new roads and sites for major public buildings--an approach that required the demolition of the historic fabric and buildings. The ancient cities of Aleppo and Damascus represent the first style of planning. In both cases, the new city was developed adjacent to the historic center and, due to growth, extended their traffic spines and new roads through the old city cutting across the historic fabric. The second approach was to develop new cities on new land without interacting with the pre-existing cities and structures. An example of the second approach is the city of Fez. The new city of Fez was planned upstream from the historic center atop a plateau. Although it was constructed with one of its major avenues pointing into the old city, the architects took care in preserving the integrity of the original settlement. The new city was able to develop and expand without infringing upon the historic urban fabric.

\section{Differences Between Traditional Islamic and Modern Western Planning}

In the Muslim world, the traditional Islamic planning methods provide a sense of culture and community, while at the same time, the Western system contradicts these vernacular customs and beliefs but brings about efficiency and rational development. The problem that arises, then, is the appropriate integration of the two methods to form a contemporary solution. The need is a viable blend between the Islamic cultural paradigm and modern technological progressive development. To ascertain the assimilation requires the correct values and objectives that will guide the planning and design process, that is, an awareness of local culture and traditions applied to the scientific, technical, and architectural tools used by modern development to favor the synthesis of these two planning methods. The differences, however, in the concepts of development, community, aesthetics, planning, land use, circulation, urban form, and architectural form are great and require further examination to understand the future of planning in the Arab city (Ben-Hamouche, 2009; Berger, 1974; Bianca, 2000; Lapidus, 1969; Roberts, 1979; Saqqaf, 1987). 
The Western thoughts of development, stemming from the ideas of the Industrial Revolution, were the concepts of efficiency and progress. From this, development was considered successful if it was represented by linear development patterns, a byproduct of the goal of efficiency. The result of this single-minded intent includes not only the neglect of geographical conditions but also the degradation of the environment, including the rapid depletion of natural resources in the name of progress (Issawi, 1969). In keeping with the logic of the rational development concept, modern institutions have divided traditional social units into more functional components to fit into an idealized plan. The new structures, then, tend to be highly artificial and never attain the life and character of the organically grown urban form. This modernization of the traditional neighborhoods results in a destruction of existing informal community networks as well.

"While modern planning is often seen as a miraculous instant solution to arising development patterns in the Third World, it appears to be even less viable there than in the Western contex" (Bianca, 2000). The problem with the Western model in the Muslim world is its assumption that it can predict for the needs of the future with precision leaving little room for change and adaption. Conventional master plans have been applied all over the Arab countries with differing results as it fails to take into account the social relationships of its human resources with its built environment. These plans tend not to adapt to the local customs and as a result, create conflicts with traditional social convention. One such area of contention is the impacts on residential development. Street plans and architectural buildings are often designed modeled after the Western model focusing much attention to the street, however, many of these designs violate the Islamic concept of privacy and neighborhood and inadvertently destroy the existing community structure.

The Western planning approach, as described by Ben-Hamouche (2009), lacks the flexibility to interact with day-to-day decisions made by governmental agencies and private land owners. It is these personal decisions that are one of the strengths of traditional Islamic planning. The ideas of community and social consensus created by the community were mechanisms that allowed for flexible planning. These social constraints allowed individuals to contribute to the organic whole through single buildings and added elements. There was no predetermined scheme that defined future development in a rigid pattern. Regardless, the societal infrastructure ensured a balance between the growth of each cellular unit at any level of the urban form. Planning was determined by the consultation of neighbors and the interest of the community. The contrast between the traditional Arab city and the modern Arab city is evidenced in the visual appearance of their respective urban forms. The first has produced a distinct type of organic order whereby each individual unit contributes to and enhances the vitality and unity of the urban form. The second has produced a sense of uniformity but is unable to attain a lively urban form, likely due to its rigid constraints and focus on comprehensive planning.

Western master plans also differ from traditional development in terms of its separation of functions, designating specified areas for housing, commerce, civic use, industrial use, and recreation. The purpose of this kind of
Figure 5

A new road in Isfahan cutting through the cellular tissue of the old city and the main souk spine. (source: Bianca, 2000) 
planning is to divide the city into sectoral components to create a more efficient and rational urban system rather than accommodate the human needs and social considerations of the populace. Streets that are too wide and highway and road systems that bisect neighborhoods (or even parts of the cities) are then introduced to try to remedy the disconnected zoning districts further cutting into the social fabric and isolating pieces of the urban form. As stated by Ben-Hamouche (2009) and Bianca (2000), the division of uses does impart functional improvements, but at the consequence of losing many human and environmental qualities. The traditional Muslim plan for neighborhoods was always based on the principle of creating integrated sub-units. In other words, each of these parts could sustain itself as a whole in and of itself.

The traditional city was subdivided, but it was organized in a way that would allow each cellular unit to operate on its own or as a component of the comprehensive urban system. One of these guiding mechanisms was the separation of public and private uses. By placing great concern on both the public realm and privacy in residential quarters, the functions of the city were easily separated, but did not result in a disruption of the urban fabric because it allowed for clustering of uses based on social need. In Muslim cities, the incomplete application of Western concepts in modern planning without understanding of traditional concepts has led to a disintegrated urban fabric. In residential areas, a separation of society based on economic and functional criteria has led to the deterioration of the social unit. In the central business districts, mosques are designed as freestanding landmarks, isolated from the physical and social urban context, ignoring the possibilities of uses as community gathering facilities. A proper understanding of cultural and social context is needed to physically integrate these two planning models. For this to happen, the structure and form of Arab land use and planning must be learned.

The street system, as a major component of planning and urban design, is also a very important source of divergence between the traditional and Western models. The traditional Muslim city was built at a pedestrian scale and, as such, was an extremely dense cityscape with a very high degree of complexity. Streets were considered secondary to the architectural framework and often appeared only as narrow internal corridors. Main thoroughfares were integrated into souks, secondary corridors into residential neighborhoods, and alleyways into the clusters of private homes. The sequence established a clear hierarchy and punctuated changes through

Figure 6 Modern master planned city of Dubai utilizing Westernized ideals of planning and design. (source: www.robertsday. com.au/cr_waterfront.html) transition, and with it, changes in social behavior and norms (Zeisel, 1981). The circulation system ensured that the network matched the character of the space and the social needs of the users. Instead of merely dividing up spaces, the circulation system worked to connect and interrelate the various components of the urban fabric.

Modern planning, however, takes a wholly different approach to the circulation network. Major axial roads are drawn, cutting into the organic urban fabric and dividing the existing comprehensive system into separated

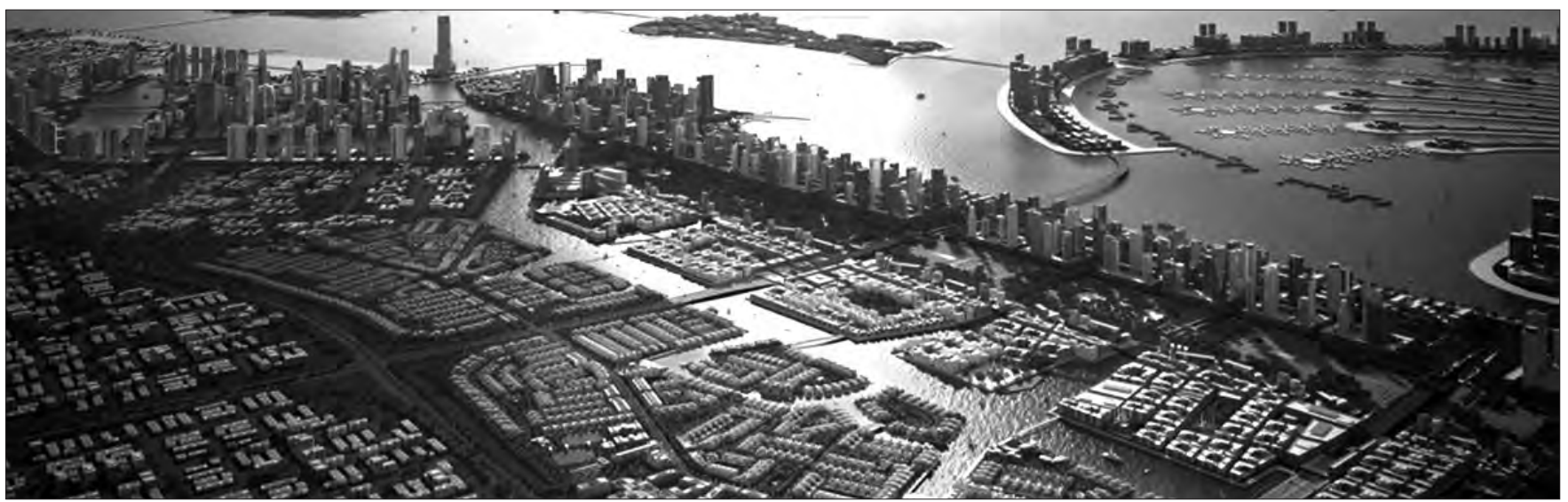


blocks. These streets disrupt the existing social blocks and divide residential neighborhoods exposing them to the public realm. In addition, applying the Western model to a preexisting settlement affects the social and spatial qualities of the traditional environment. While circulation is improved, widened roads and streetscapes are designed with the intention of enhancing important civic structures such as mosques and sanctuaries, unintentionally separating the public buildings from the urban fabric and isolating them as individual buildings. Modern circulation pathways in the traditional city also serve as redevelopment opportunities catering to the new vehicular access channels. While these infrastructure improvements are needed to revitalize and rehabilitate old cities, modern buildings that come from such developments often do not possess the same aesthetic qualities or contextual properties necessary for the environment. These buildings lack the same physical and functional qualities that allow them to become part of the cellular whole. Application of the modern planning approach, though, is still possible. With better understanding of the traditional infrastructure and the qualities inherent in the existing system, improved accessibility can be achieved without the cost of contextual destruction.

The concepts of urban form between the traditional urban form and the modern urban form have, in addition, a very important underlying difference. While the Western model follows a quantitative subdivision approach in land management creating smaller fragments of space from a larger space, the concept of urban form in a traditional Arab city is governed by an incremental and organic additive formation of parts. These small subunits are then connected together forming the larger cellular units that create the structure and tissue of the city. The multiplication and addition of units is the basis of the generating principle in the city's traditional urban form. Open space in the form of courtyards and circulation systems, instead of being parsed out, are integrated within the system. Each element of the urban fabric is developed according to the needs of the population and tailored to the human activities taking place in the community. Because of this growth pattern, every component is significant and is not created merely because there is space. The question now, as posed by Issawi (1969), is how to sustain such urban form qualities and how to integrate them into a contemporary design language.

Differences between traditional and modern approaches to architectural form have been discussed throughout this article, but it bears another mention to fully grasp the contrast in formal qualities. Much of the modern architecture designed for the contemporary city tends to be buildings isolated in an emptied urban space lacking the essential cultural qualities that made it correspond to the community. In addition, many structures are reduced to a repetitive grid pattern and mirror the Western subdivision practices of homes and buildings lacking any cultural identity. As mentioned previously, traditional Arab residences and architecture is conceived not as detached objects, but shaped according to the needs of the users. The design and layout of the building matches the location in which it was developed and with it the ability to integrate into the existing urban fabric. The building itself is an interior focused space, very different from the idea of Western architecture where the dominant features are seen from the exterior. Street elevations are of little importance in the Muslim world as the architecture's spatial qualities are to be experienced inside. Architecture of

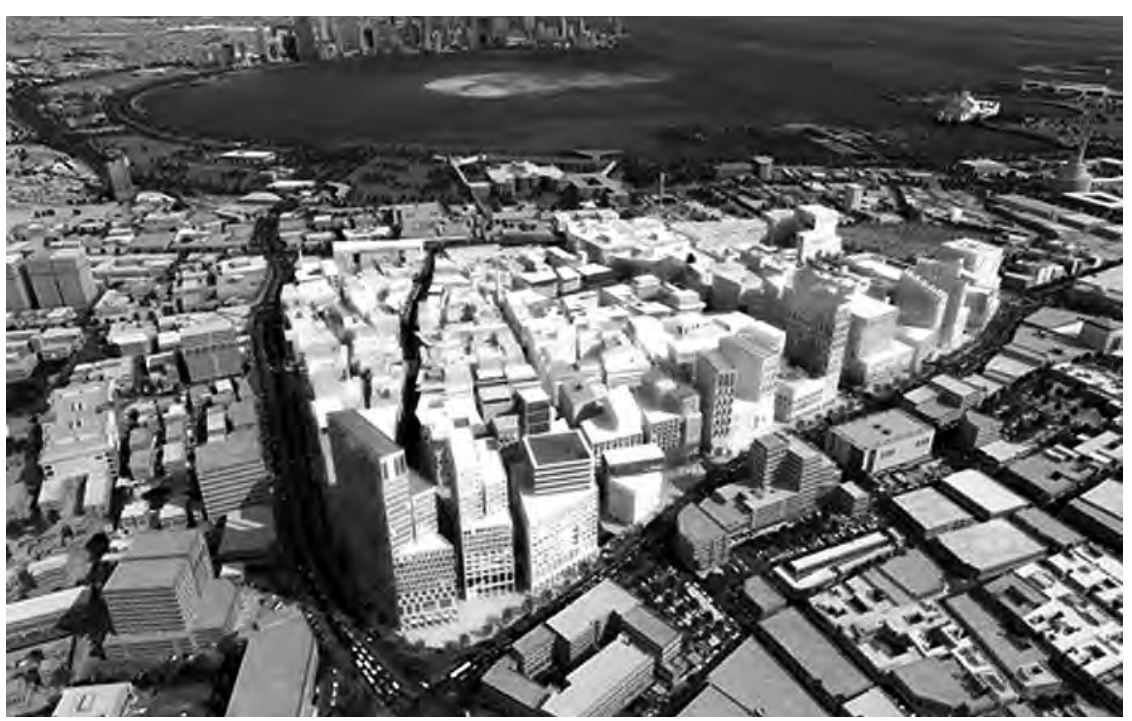

\section{Figure 7}

The Heart of Doha, Qatar, a project by AECOM utilizes the existing city fabric as a precedent and incorporates sustainable strategies and design standards for a new city center. (source: AECOM Technology) 
the Western world on the other hand is fundamentally different in regards to access, street orientation, and contextual aesthetics. To be able to fully fit within the urban context, new architectural models of development need to be established.

\section{Final Remarks: Integrating Tradition and Modernity}

The ultimate objective of the present analysis is to suggest how to bridge the gap between the differences of the East and the West, past and present, or traditional planning and contemporary planning. The only way to do this is by understanding and applying the essential values of the local tradition with Western technology and architectural concepts with regards to their underlying ideologies and social implications. This integration will need to adapt to meet the needs of contemporary Arab cities but still retain cultural continuity between the needs of social society and progressive planning. These fundamental issues can only be resolved by dialogue and shared values between all parties involved and strong participation from local voices. In addition, every situation can hardly be resolved by a generalized answer. The dynamic nature of the urban form can hardly be accommodated by either of the extreme conditions presented but should be responded to in a meaningful and appropriate manner, maintaining, adapting or reinterpreting traditional structures where possible, and developing new structures for emerging needs. Reinterpretation of tradition based on modern needs may be necessary, but should remain faithful to traditional typological and morphological principles and follow cultural and urban continuity.

\section{References}

Berger, Morroe (ed.). 1975. The New Metropolis in the Arab World. New York: Octagon Books.

Bianca, Stefano. 2000. Urban Form in the Arab World: Past and Present. New York: Thames \& Hudson.

Gulick, John. 1969. Village and City: Cultural Continuities in Twentieth Century Middle Eastern Cultures. In Middle Eastern Cities edited by Lapidus. Berkeley and Los Angeles. University of California Press.

Franck, Karen. 1994. Types are Us. In K. Franck \& L. Schneekloth (eds) Ordering Space: Types in Architecture and Design. Portland: Wiley \& Sons.

Issawi, Charles. 1969. Economic Change and Urbanization in the Middle East. In I. Lapidus (ed) Middle Eastern Cities. Berkeley: University of California Press.

Lapidus, Ira M. 1969. Middle Eastern Cities. Berkeley: University of California Press.

Roberts, Hugh. 1979. An Urban Profile of The Middle East. New York: St. Martin's Press.

Saqqaf, Abdulaziz Y. 1987. The Middle East City. New York: Paragon House.

Shiber, Saba G. 1969. Recent Arab City Growth. Kuwait, Saudi Arabia: Kuwait Government Printing Press.

Zeisel, John. 1981. Inquiry by Design. Monterey, CA: Brooks/Cole Publishing Co. 